\title{
Quality of anticholinergic burden scales and their impact on clinical outcomes: a systematic review
}

\author{
Angela Lisibach ${ }^{1,5,6}$ D $\cdot$ Valérie Benelli $^{1}$ • Marco Giacomo Ceppi ${ }^{2,3} \cdot$ Karin Waldner-Knogler $^{4} \cdot$ Chantal Csajka $^{5,6}$. \\ Monika Lutters ${ }^{1,7}$
}

Received: 9 March 2020 / Accepted: 10 September 2020 / Published online: 3 October 2020

(C) The Author(s) 2020

\begin{abstract}
Purpose Older people are at risk of anticholinergic side effects due to changes affecting drug elimination and higher sensitivity to drug's side effects. Anticholinergic burden scales (ABS) were developed to quantify the anticholinergic drug burden (ADB). We aim to identify all published ABS, to compare them systematically and to evaluate their associations with clinical outcomes.

Methods We conducted a literature search in MEDLINE and EMBASE to identify all published ABS and a Web of Science citation (WoS) analysis to track validation studies implying clinical outcomes. Quality of the ABS was assessed using an adapted AGREE II tool. For the validation studies, we used the Newcastle-Ottawa Scale and the Cochrane tool Rob2.0. The validation studies were categorized into six evidence levels based on the propositions of the Oxford Center for Evidence-Based Medicine with respect to their quality. At least two researchers independently performed screening and quality assessments.

Results Out of 1297 records, we identified 19 ABS and 104 validations studies. Despite differences in quality, all ABS were recommended for use. The anticholinergic cognitive burden (ACB) scale and the German anticholinergic burden scale (GABS) achieved the highest percentage in quality. Most ABS are validated, yet validation studies for newer scales are lacking. Only two studies compared eight ABS simultaneously. The four most investigated clinical outcomes delirium, cognition, mortality and falls showed contradicting results.

Conclusion There is need for good quality validation studies comparing multiple scales to define the best scale and to conduct a meta-analysis for the assessment of their clinical impact.
\end{abstract}

Keywords Cumulative anticholinergic burden $\cdot$ Clinical outcomes · Older people $\cdot$ Quality assessment · Validation

Electronic supplementary material The online version of this article (https://doi.org/10.1007/s00228-020-02994-x) contains supplementary material, which is available to authorized users.

Angela Lisibach

angela.lisibach@ksb.ch

$\checkmark$ Chantal Csajka

Chantal.Csajka@chuv.ch

1 Clinical Pharmacy, Department Medical Services, Cantonal Hospital of Baden, Baden, Switzerland

2 Department of Neurorehabilitation, RehaClinic, Bad Zurzach, Switzerland

3 Basel Pharmacoepidemiology Unit, Division of Clinical Pharmacy and Epidemiology, Department of Pharmaceutical Sciences, University of Basel, Basel, Switzerland
4 Qualitätszentrum für Medikamentensicherheit, Mediq, Brugg, Switzerland

5 Center for Research and Innovation in Clinical Pharmaceutical Sciences, Institute of Pharmaceutical Sciences of Western Switzerland, University Hospital and University of Lausanne, Lausanne, Switzerland

6 School of Pharmaceutical Sciences, Institute of Pharmaceutical Sciences of Western Switzerland, University of Lausanne, University of Geneva, Geneva, Switzerland

7 Swiss Federal Institute of Technology, Zurich, Switzerland 


\section{Introduction}

Epidemiologic studies have shown that $50 \%$ of the older population uses at least one drug with anticholinergic $(\mathrm{ACH})$ properties. This is due to their use for multiple indications such as urinary incontinence or sleep disorders [1]. Furthermore, prescription increases with hospitalization [1-3]. Patients above the age of 65 years are at higher risk of experiencing ACH side effects due to physiological changes such as a decline in renal and liver function affecting drug elimination, changes in body mass distribution or increased blood-brain barrier (BBB) permeability [4-6]. ACH side effects are separated into peripheral (e.g. mouth dryness, blurred vision) and central (e.g. dizziness, mental confusion) side effects depending on the drug's ability to pass the BBB. It has been shown that the increase in $\mathrm{ACH}$ side effects could result in negative clinical outcomes [3].

In 2001, Tune et al. defined the "anticholinergic burden" as a cumulative effect of taking one or more drugs susceptible to inducing ACH adverse effects [7]. It is important that clinicians have a valid method of measuring the ACH burden at their disposal to reduce such negative effects.

Presently, there is no gold standard for assessing the $\mathrm{ACH}$ burden in a patient. The two current major methods are the serum radioreceptor anticholinergic activity assay (SAA) and expert-based lists of medications with $\mathrm{ACH}$ properties, the so-called anticholinergic burden scales (ABS) or equations. The ABS generally assign a number from 0 (=no) to 3 (=high) to each substance according to its $\mathrm{ACH}$ properties. The first step in calculating the $\mathrm{ACH}$ burden of patients is done by identifying all prescribed $\mathrm{ACH}$ drugs followed by adding up the scores of each substance (cumulative ACH burden). The resulting score helps identifying patients at high risk of adverse events and provide guidance on interventions. Rudd et al. stated that these expert-based lists are the sole clinically useful tool to measure central ACH burden [8]. Apart from the expert-based lists are also equation-based approaches calculating the drug burden of a patient. Therefore, the drug burden is calculated using an equation, which includes dailyprescribed dosage and minimum recommended daily dosage and neglects ACH properties [9].

So far, we have identified five reviews describing ABS and their validation studies [6, 9-12]. However, these were descriptive reviews lacking systematic quality assessments for both the ABS and their validation studies. In this review, we aim to identify all published ABS and their validation studies, assess the quality of the ABS and their validation studies based on a systematic approach using adapted tools and evaluate their associations with clinical outcomes.

\section{Methods}

\section{Search strategy and selection criteria}

A systematic review was undertaken in accordance with the PRISMA statement [13]. We conducted a literature search in MEDLINE and EMBASE in March 2019 without date limitation but language restriction to German, French and English to identify all published ABS. The search was updated prior to the submission of this article to identify any new publication. The exact search queries for both databases are depicted in Appendix 1.

Following the first literature search, a citation analysis was performed using Web of Science (WoS) to track validation studies for all identified ABS and relating them to clinical outcomes. Both searches were supplemented by manual searching of reference lists of the selected studies (snowballing). All found articles were imported to a citation manager (Endnote) and duplicates were removed. A flowchart of the search strategy is depicted in Fig. 1; a separate and detailed flowchart for the identification of all validation studies can be found in Appendix 2.

Inclusion criteria for the ABS were (1) existence of a grading score for each medication, (2) availability of a medication list and (3) development of the ABS for adults' $\geq 18$ years. We excluded ABS that were based on an equation calculating the ACH burden score for each substance. The corresponding authors were asked to provide an updated version of the included scales if no reference thereof could be found in the literature.

Inclusion criteria for the validation studies were (1) use of one of the identified ABS and calculation of the cumulative $\mathrm{ACH}$ burden, (2) evaluation of at least one clinical outcome, (3) inclusion of adults $\geq 18$ years and (4) study designs: randomized controlled trial (RCT), cohort and case-control or cross-sectional studies. We excluded all validation studies that used the ABS to differentiate between users and non-users of $\mathrm{ACH}$ medication and study designs such as case reports, letters, pilot studies, case series, editorials and conference abstracts.

Two independent researchers (AL, VB) performed article screening and selection. Disagreements among the researchers were discussed with a third researcher (ML) until consensus was reached.

\section{Data extraction}

Two researchers (AL, VB) independently extracted data onto a standardized spreadsheet. For the ABS, we extracted the following data: abbreviation, name of ABS, country/year, author, update, number of drugs scored, scoring levels, expert committee, description of scoring process or of resolving discordance among experts or previous lists 


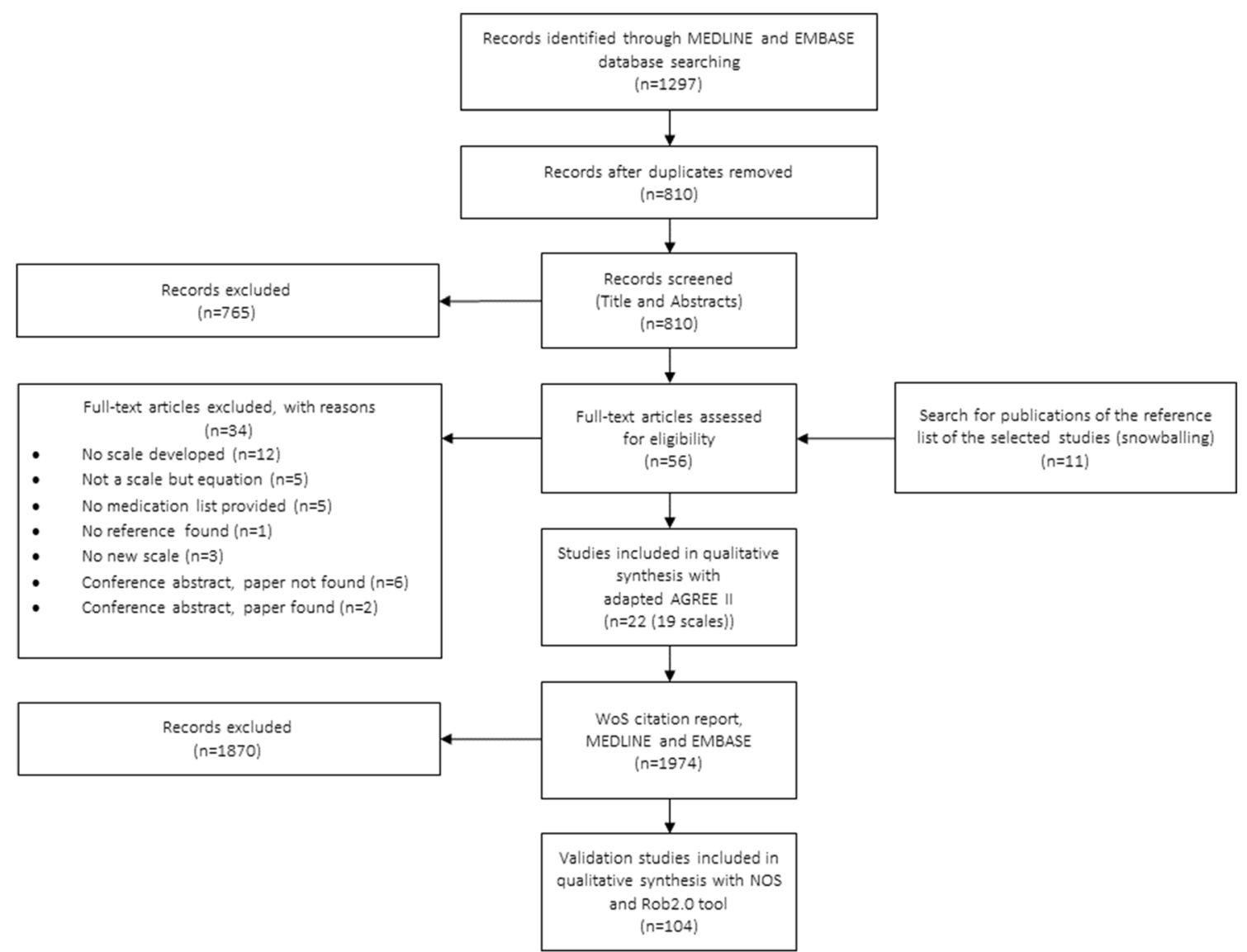

Fig. 1 PRISMA flowchart. The identification of all published ABS and their validation studies (a detailed separate flowchart for the validation studies is depicted in Appendix 2)

and source of evidence (clinical expert opinions, dosage consideration, SAA/muscarinic receptor affinity, $\mathrm{ACH}$ adverse drug events, drug interaction, administration route, $\mathrm{BBB}$ permeability and based on prior published $\mathrm{ABS}$ ). For the validation studies, we extracted the following data: author, title, year, used ABS, number of compared ABS, study design, study population, clinical outcome(s) and association studied.

\section{Quality assessment of scales}

In a next step, we used the AGREE II tool to compare the ABS by systematically assessing their quality [14]. As the tool was originally developed and used for the quality assessment of clinical guidelines, we treated the ABS as individual guidelines. Prior to use, four researchers (AL, VB, KWK, ML) analyzed the tool independently and made suggestions for adaptions of the tool items. These were discussed and a consensus was reached. The adapted AGREE II tool can be found in Appendix 3. From 23 items, it was shortened to 18 items in 6 domains (deleted items from the Original AGREE tool II were number 5, 11, 16, 18, 20, 21). Furthermore, we added the item "Suggestions for further research" and changed
"External review" into "Validation of scale". For the item "Validation of scale", we provided the researchers with a spreadsheet of all validation studies with their quality and evidence level as described below. Three researchers (AL, MGC, ML) independently assessed the quality of each ABS using the adapted AGREE II tool and scored each item from 1 (lowest) to 7 (highest). We also asked the researchers to provide an overall assessment score of the ABS and to state if they would recommend it for use. The analysis was performed according to the AGREE II tool manual with the exception that item 7 "Evidence selection criteria" and 11 "Validation of scale" were counted twice as they were considered more important. Absolute agreement of the three researchers was assessed by calculating the intraclass correlation coefficient (ICC) with a two-way model.

\section{Risk of bias of validation studies}

In a next step, two researchers (AL, ML) independently appraised the quality of all validation studies using two published tools depending on the study design. For cohort, casecontrol and cross-sectional studies, we used the NewcastleOttawa Scale (NOS) [15] and for the RCT Risk of bias 2.0 
(Rob2.0) from the Cochrane Collaboration [16]. We adapted the NOS for case-control studies by changing the "Non-response Rate" to "Missing Data". For cross-sectional studies, we used the NOS for cohort studies by changing in Selection "3) Ascertainment of exposure" into "3) Measurement of method of exposure" and in Outcome "3) Adequacy of follow-up of cohorts" into "3) Missing data for cross-sectional". Additionally for cross-sectional studies, we answered Selection "4) Demonstration that outcome of interest was not present at start of study or baseline measurement" and Outcome "2) Was follow-up long enough for outcomes to occur" always with a "no". The forms can be found in the Appendix 4. The scores from the NOS and RoB2.0 were transformed into Agency for Healthcare Research and Quality standards (AHRQ) of "good", "fair" or "poor" quality according to the conversion rules (Appendix 5). Considering the quality standards, we categorized each study into one of the evidence levels: 1 RCT (good and fair quality), 2a RCT (poor quality) and prospective cohort studies (good and fair quality), $2 \mathrm{~b}$ retrospective cohort studies (good and fair quality), 3 case-control studies (good and fair quality), 4 cohort and case-control studies (poor quality) and 5 cross-sectional studies (good, fair and poor quality). The levels were based on the propositions of the Oxford Center for Evidence-Based Medicine [17]. Two researchers (AL, ML) independently assessed the quality and assigned evidence levels. Disagreements in assessment were resolved by discussion.

As the included studies were very heterogeneous, we refrained from conducting meta-analysis for clinical outcomes.

\section{Software use}

Graphical demonstrations and calculations were performed in R Studio [18-22].

\section{Results}

\section{Identification of published ABS and their validation studies}

Out of 1297 records identified in the database and additional 11 records through snowballing, 24 studies describing 22 different ABS [23-46] were selected (Fig. 1). We excluded two studies by Aizenberg et al. [45] and by Whalley et al. [46], as no medication list was provided after contacting the authors, resulting in a total of 22 records describing 19 different ABS[23-44]. The updated search revealed no new scale. Our search query also identified the often used DBI (Drug Burden Index) and ACH-DBI [47, 48], the Drug Delirium Scale (DDS) [49], the scale by Cao [50] and the most recently developed MARANTE scale [51]. However, these five ABS were excluded as they were based on equations. The Summated Anticholinergic Medications Scale (SAMS) identified in the paper by Naples et al. [52] was excluded since no proper reference was found.

The 19 unique ABS (Table 1) arise from 11 different countries (USA, Thailand, Brazil, Germany, Korea, Canada, Norway, Ecuador, France, UK and Italy). Four scales (DS [32], GABS [38], KABS [37], BAADS [40]) have been elaborated by summarizing scores of previous published scales through an algorithm to develop a new score. For the GABS and the KABS, an expert committee scored some new drugs, while the other two did not state any expert committee nor scoring of new drugs. Most of the other ABS were developed by a literature research identifying $\mathrm{ACH}$ properties for each substance complemented by clinical expertise. These properties were mainly muscarinic receptor affinity, BBB permeability, drug interactions, $\mathrm{ACH}$ adverse events and serum radioreceptor anticholinergic activity assay (SAA). The Chew's scale and the ATS were developed differently. While the Chew's scale is based on an in vitro SAA measurement, the ATS is the only scale based on computational receptor binding affinity. Most ABS used a four-level grading system from 0 to 3 except for the DS [32] (high and low), the AAS [33] (5 levels), the Chew scale [31] (5 levels), the ATS [44] (continuous values), the SCDL [36] (3 levels) and the CI, PI (relative continuous values) [39]. Overall 787 different substances have been scored.

Additionally, we were able to outline the relationship and dependencies of the identified ABS with one another. We found nine $\mathrm{ABS}$ that are not based on a prior published scale (Fig. 2). These are the ABC, ACB, AEC, ARS, ATS, CABS, Chew, SCDL and CI, PI.

Our citation report analysis identified 104 validation studies [33-36, 39, 41, 44, 53-149] (Fig. 1, Appendix 2 and 6). We included one more study, when the search was updated [136]. Twenty reports compared more than one ABS leading to 147 evaluations with different clinical outcomes. The ACB, ADS and ARS are the scales mostly used while five ABS (AEC, AIS, BAADS, GABS and KABS) have not been validated yet (Fig. 3).

\section{The quality of the identified ABS and their validation studies}

The ACB scale [25] and the GABS [38] reached with $75 \%$, the highest overall assessment percentage, while the SCDL [43] received the lowest with $11 \%$ (Table 2). Focusing on domain 3 to 5 ("Rigor of development", "Clarity of presentation" and "Applicability"), which were considered most important for clinical and research use, the ACB scale [25] reached the highest percentage in all three domains $(62 \%$, $89 \%, 72 \%)$ together with the GABS [38] for domain 5 (72\%). The lowest percentage were achieved in domain 3 by 


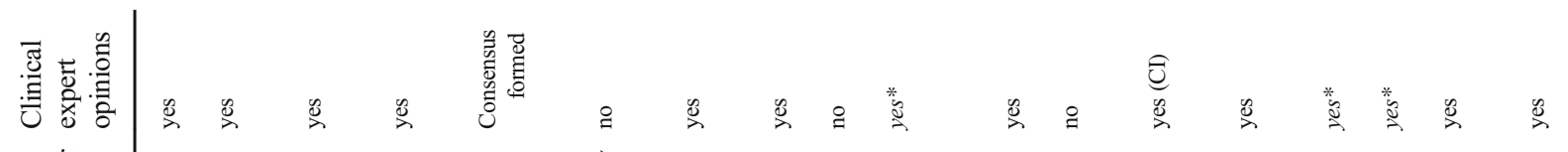

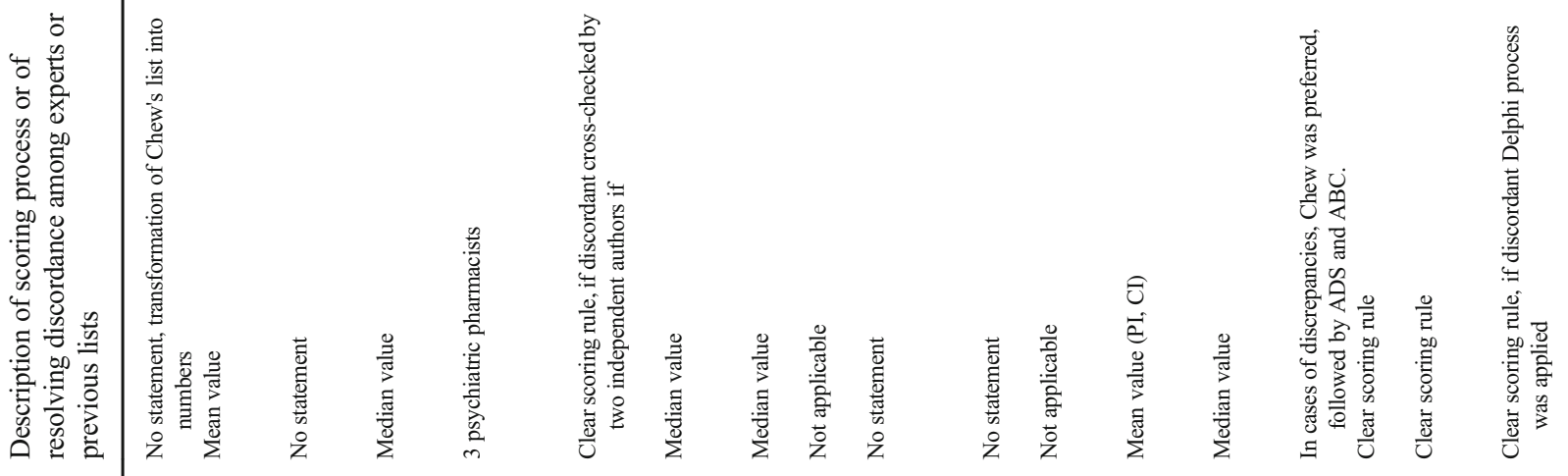

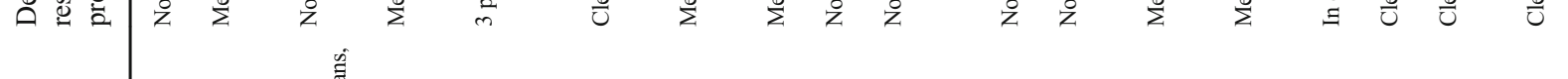

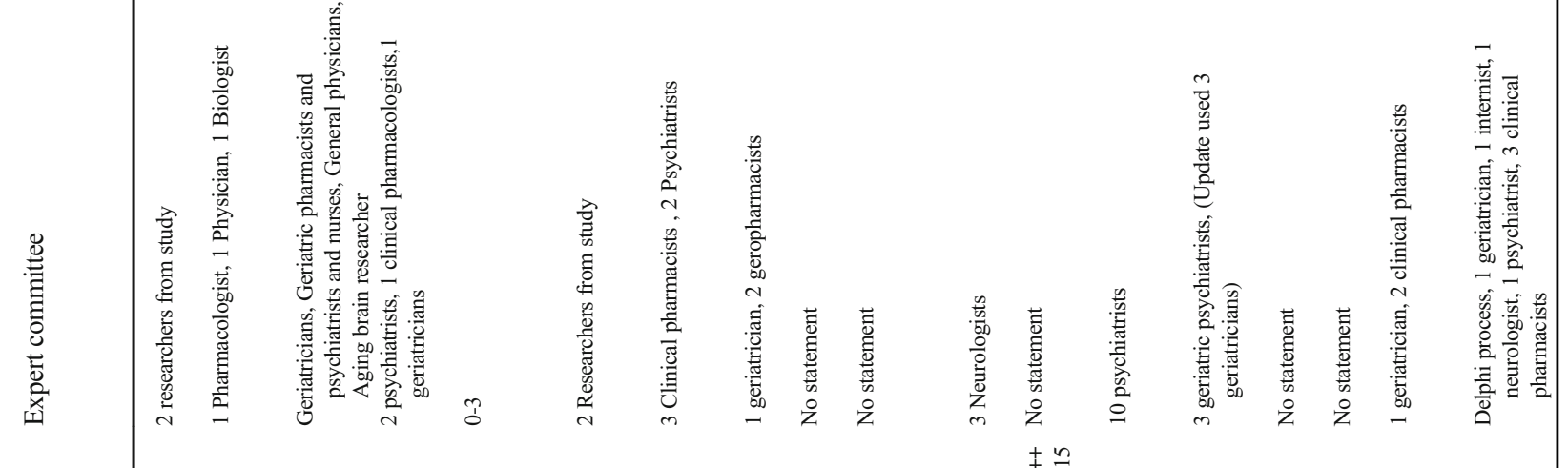

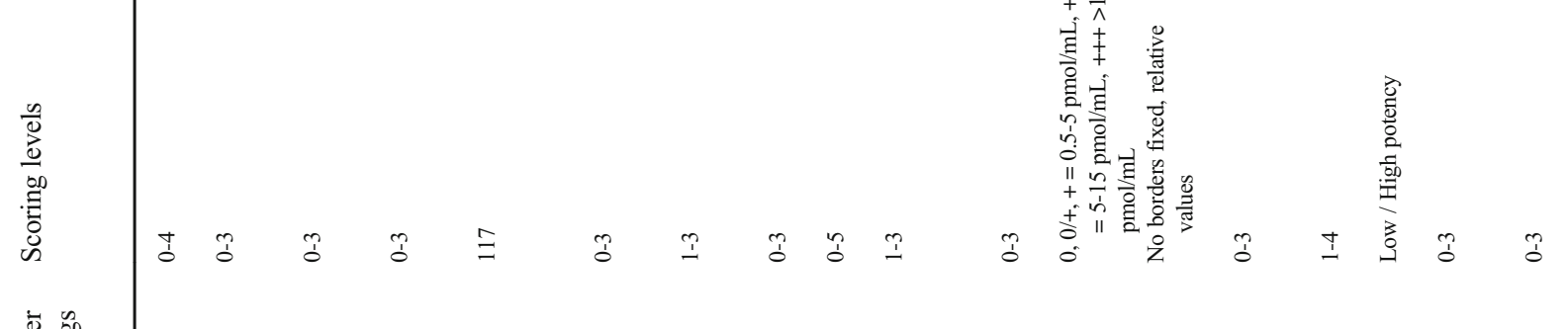

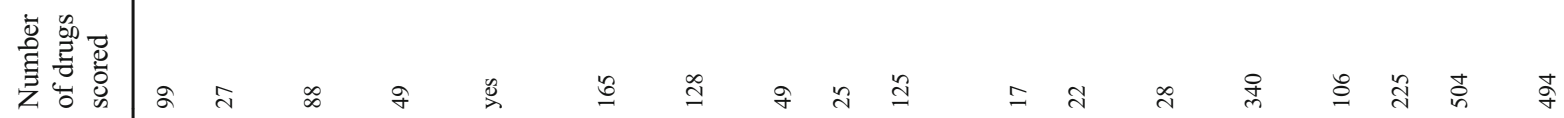

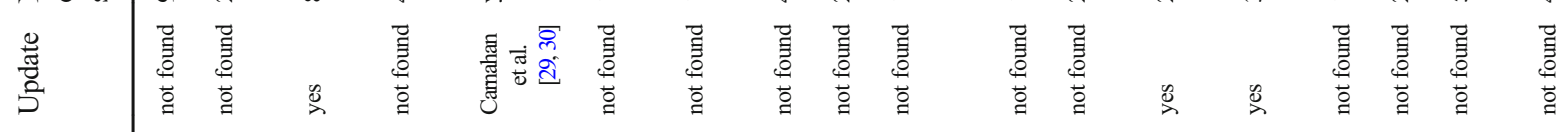

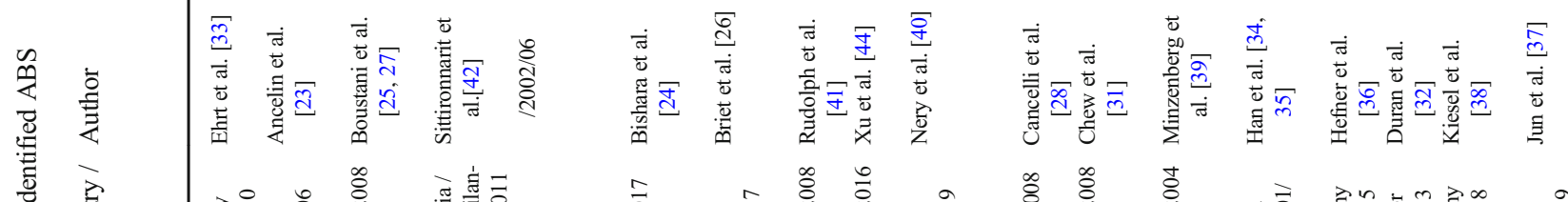

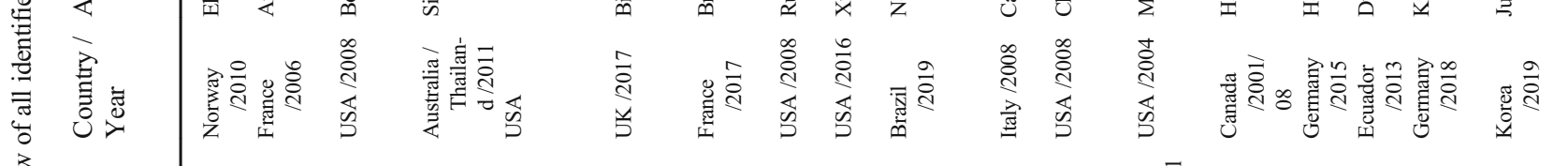

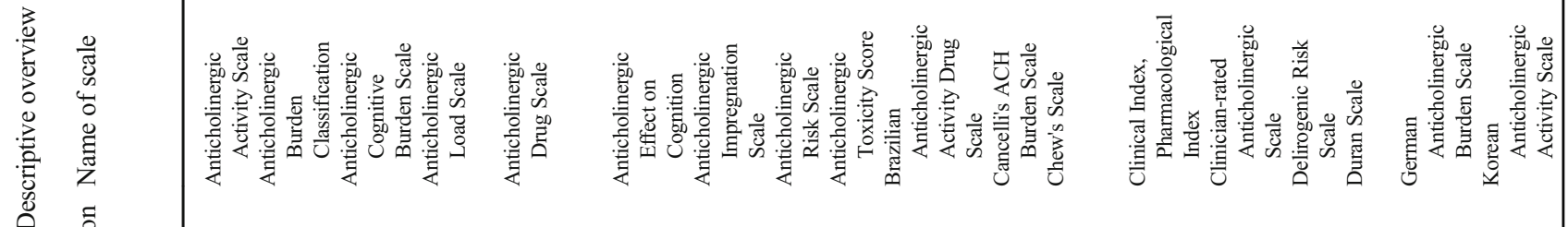

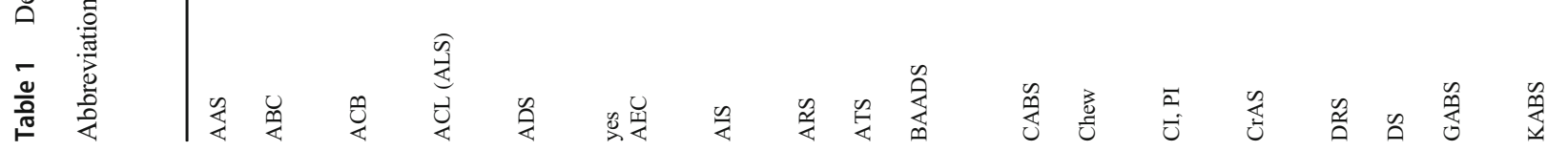









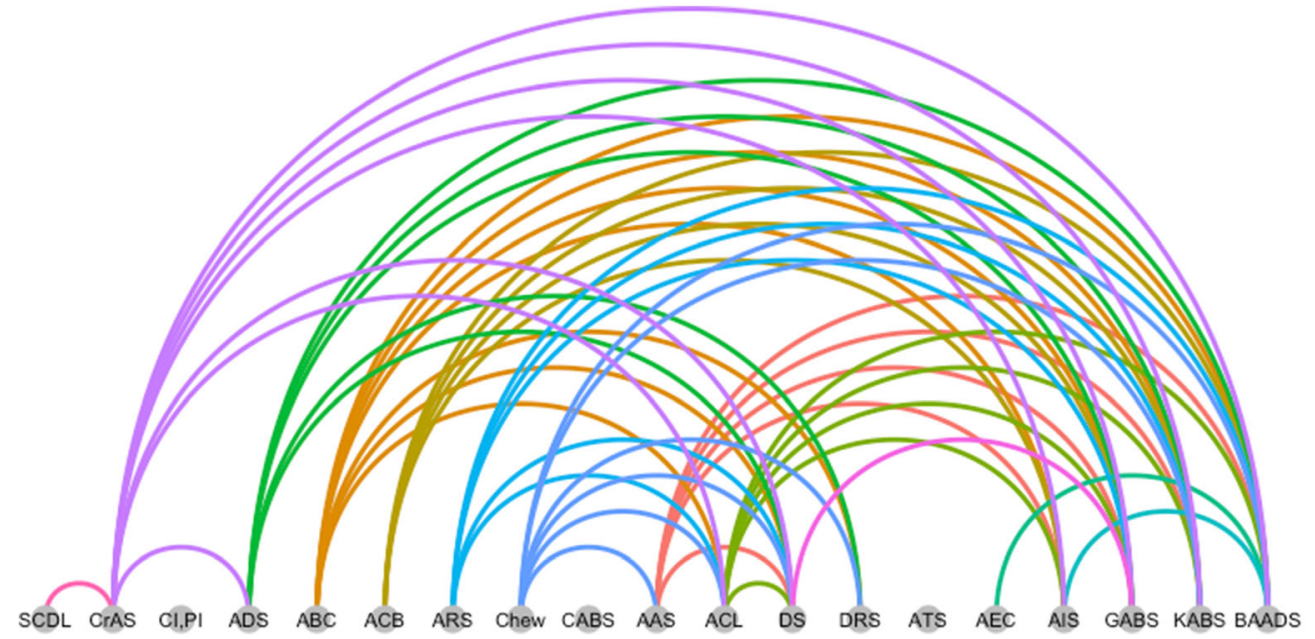

Abbreviations

- AAS

- $\mathrm{ABC}$

- $\mathrm{ACB}$

- $\mathrm{ACL}$

- $A D S$

- AEC

- AlS

- ARS

- Chew

- Cras

- DS

- SCDL

Fig. 2 Relationship of the anticholinergic burden scales (ABS) sorted by the year of publication (from 1978 to 2019). Example of reading the figure: The SCDL is included in the CrAS or the CrAS is included in the ADS

the SCDL (16\%) [43], domain 4 by the ABC scale (8\%) [23] and domain 5 by the ABC [23], CABS [28], CI and PI [39] scales and ATS [44] (6\%). In terms of clinical applicability, only the ACB, GABS and AEC provided an advice on how to apply the scale in clinical practice. The three scales agreed that a change in medication should be performed in a patient with a total ACB score $>2$. Based on the quality assessment of the
ABS with the adapted AGREE II tool, at least two out of three appraisers recommended all 19 ABS for use with modifications. The intraclass coefficient for absolute agreement was 0.89 with a $95 \%$-CI ranging from $0.86-0.92$, showing high agreement among the three appraisers [150].

The 104 validation studies consisted of 1 RCT (good quality) [98], 74 cohort studies (50 good and 24 poor quality)
Fig. 3 Count of validations per scale. Number of scale validations according to their level of evidence (total $n=147$ ). The bubble size is proportional to the number of validations per scale indicated as the numbers in the center of the bubble. Five ABS (AEC, AIS, BAADS, GABS and KABS) have not been validated yet

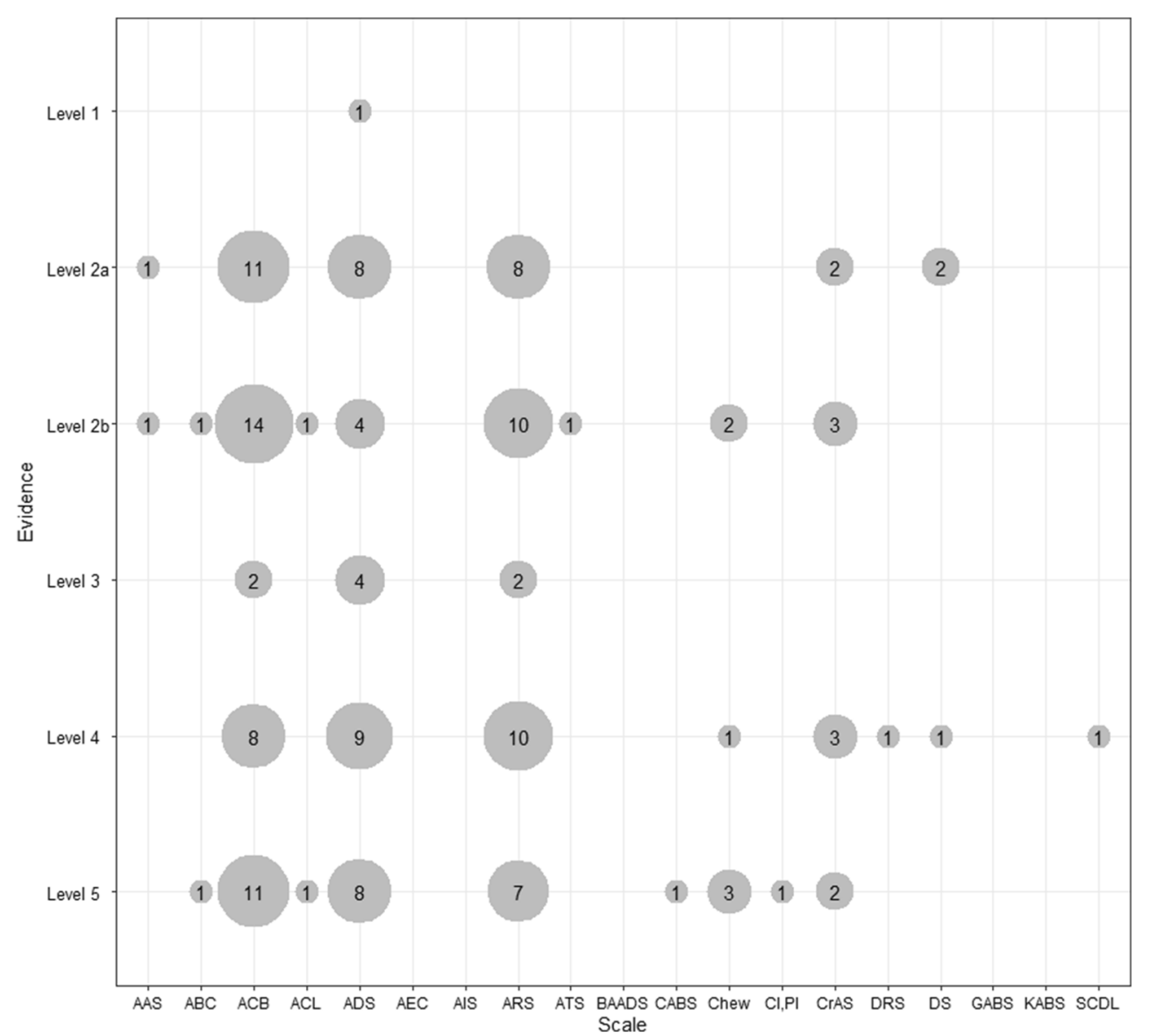


Table 2 Systematic quality assessment of ABS by the adapted AGREE II tool

\begin{tabular}{|c|c|c|c|c|c|c|c|}
\hline Domain & $\begin{array}{l}\text { Domain 1: Scope } \\
\text { and Purpose (\%) }\end{array}$ & $\begin{array}{l}\text { Domain 2: } \\
\text { Stakeholder } \\
\text { involvement (\%) }\end{array}$ & $\begin{array}{l}\text { Domain 3: Rigour of } \\
\text { development (\%) }\end{array}$ & $\begin{array}{l}\text { Domain 4: Clarity } \\
\text { of presentation (\%) }\end{array}$ & $\begin{array}{l}\text { Domain 5: } \\
\text { Applicability } \\
(\%)\end{array}$ & $\begin{array}{l}\text { Domain 6: Editorial } \\
\text { independence }(\%)\end{array}$ & $\begin{array}{l}\text { Overall } \\
\text { assessment } \\
(\%)\end{array}$ \\
\hline AAS & 59 & 28 & 31 & 28 & 17 & 65 & 33 \\
\hline $\mathrm{ABC}$ & 52 & 36 & 25 & 8 & 6 & 70 & 25 \\
\hline $\mathrm{ACB}$ & 67 & 64 & 62 & 89 & 72 & 89 & 75 \\
\hline ACL & 61 & 56 & 38 & 28 & 17 & 4 & 28 \\
\hline ADS & 65 & 56 & 51 & 42 & 33 & 94 & 61 \\
\hline $\mathrm{AEC}$ & 70 & 64 & 49 & 78 & 56 & 87 & 72 \\
\hline AIS & 65 & 50 & 25 & 42 & 39 & 48 & 25 \\
\hline ARS & 70 & 75 & 58 & 67 & 33 & 50 & 67 \\
\hline ATS & 74 & 31 & 40 & 39 & 6 & 87 & 36 \\
\hline BAADS & 61 & 25 & 30 & 50 & 28 & 46 & 31 \\
\hline CABS & 54 & 28 & 23 & 14 & 6 & 31 & 17 \\
\hline Chew & 67 & 42 & 38 & 47 & 22 & 54 & 47 \\
\hline CI, PI & 74 & 39 & 30 & 25 & 6 & 35 & 28 \\
\hline CrAS & 57 & 44 & 54 & 31 & 22 & 61 & 53 \\
\hline DRS & 67 & 28 & 31 & 44 & 17 & 11 & 33 \\
\hline DS & 63 & 39 & 52 & 33 & 33 & 91 & 72 \\
\hline GABS & 67 & 83 & 45 & 81 & 72 & 85 & 75 \\
\hline KABS & 56 & 75 & 42 & 42 & 28 & 72 & 56 \\
\hline SCDL & 39 & 8 & 16 & 25 & 11 & 6 & 11 \\
\hline $\begin{array}{l}\text { Highest } \\
\text { value }\end{array}$ & 74 & 83 & 62 & 89 & 72 & 94 & 75 \\
\hline $\begin{array}{l}\text { Lowest } \\
\text { value }\end{array}$ & 39 & 8 & 16 & 8 & 6 & 4 & 11 \\
\hline $\begin{array}{l}\text { Median } \\
\text { value }\end{array}$ & 65 & 42 & 38 & 42 & 22 & 61 & 36 \\
\hline
\end{tabular}

Numbers are scaled percentages for each domain 1-6 and the overall assessment calculated for interdomain comparison according to the manual

$[33-36,41,44,54,55,57,59,61-66,70-75,77,78,80,81$, 83-97, 100, 103-108, 112-115, 117, 119, 120, 123, 124, 129, 131-137, 139, 141-146, 148, 149], 9 case-control studies (6 good, 1 fair and 2 poor quality) [56, 67-69, 102, 110, 118, $130,147]$ and 20 cross-sectional studies ( 2 good and 18 poor quality) $[39,53,58,60,76,79,82,99,101,109,111,116$, 121, 122, 125-128, 138, 140] (Appendix 6). More than half of the studies were judged to be of good quality (60 out of 104). There was only 1 RCT by Kersten et al. validating the ADS.

\section{Impact of ABS on clinical outcomes}

From the 147 evaluations, 15 reported on delirium $[35,55,62$, $65,74,80,96,112,126,144,149], 54$ on cognition [33, 34, 39, 57-61, 64-66, 71, 73, 76, 79, 82, 83, 97-99, 106, 107, $109,114,121,127,128,140,145,146,148], 20$ on mortality $[55,68,72,75,80,84,85,89,100,108,113,115,117,119$, $120,123,132,134,137,141]$ and 24 on falls $[53,87,93,112$, 118, 121, 129, 131, 136, 147] (Fig. 4). As Fig. 4 demonstrates, the results are contradicting on all evidence levels. Yet, for all of these four clinical outcomes, the majority of studies show a positive association. In terms of study design, especially for falls and cognition, we identified many cross-sectional studies (cognition 27 out of 54, falls 9 out of 24) in contrast to delirium and mortality (delirium 1 out of 15 , mortality 0 out of 20 ).

Other outcomes investigated in the studies can be found in (Appendix 6).

There is no study comparing the clinical performance of all published ABS in the measure of the cumulative ACH burden and its relationship with a clinical outcome. Only two out of the twenty reports comparing more than two ABS included up to eight ABS [121, 131]. These two reports consist of a crosssectional study with poor quality (Level 5) [121] and a cohort study with good quality (Level 2b) [131]. Both of these studies investigated falls, where four ABS (ABC, ACB, ADS, CrAS) showed contradicting associations whereas three (ACL, ARS, Chew) agreed upon a positive association.

\section{Discussion}

We identified 19 different published ABS and assessed their quality systematically. Among those ABS, 6 (GABS, KABS, 


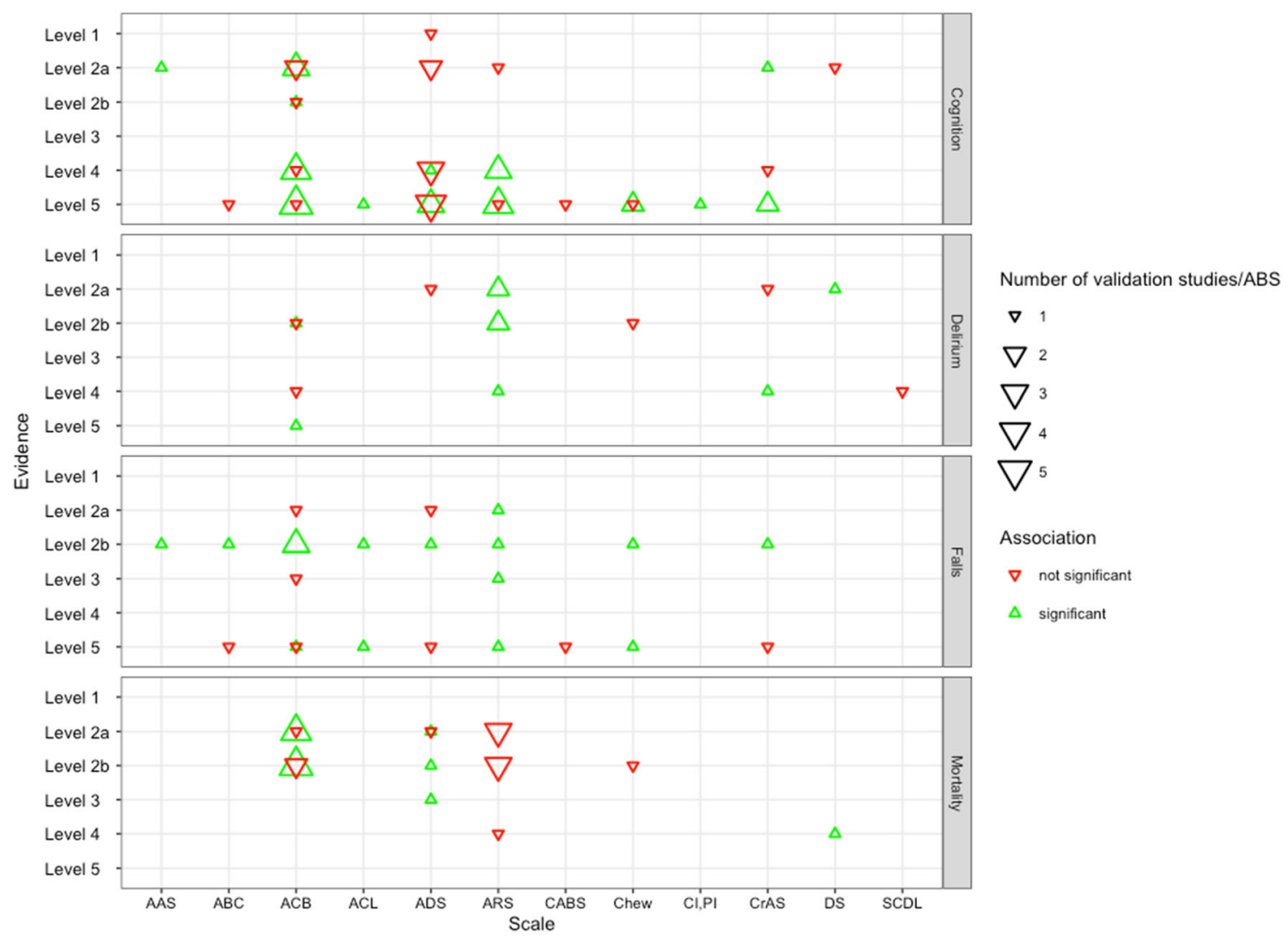

Fig. 4 Found association of the validation studies with the most investigated clinical outcomes. Number of scale validations according to their evidence levels and grouped by the four most investigated clinical outcomes (total $n=118$ ). The triangle size is proportional to the number of validations and an upward triangle means statistically significant association
ATS, DRS, AIS and AEC) have not been included in previous systematic reviews [6, 9-12]. Although at least two out of three appraisers recommended all scales for use with some modifications, their quality varied greatly. Firstly, although we were able to identify the source of evidence (e.g. BBB permeability, muscarinic receptor affinity), the clear explanation of the scoring rule and reproducibility of the scoring process was not always completely stated or left out. Secondly, the expert committee used for the development process varied in terms of number of experts and their field of expertise. Thirdly, most of the ABS were developed in the early 2000s, whereas only a few were published only recently. Hence, in the latter scores, there was not enough time to conduct a validation study. Our findings confirm as previously shown that no ABS can be considered a gold standard [52, 151].

Although more than half of the validation studies were of good quality and included sometimes an impressive sample size, many of them were cross-sectional studies, a design that is not optimal to assess adverse drug effects since ascertainment of exposure prior to outcome is not guaranteed. Classical RCTs, in which patients are randomly divided into treatment and placebo groups, are considered the highest level of evidence, but are not feasible here due to ethical issues. In this context, good quality cohort studies are best suited to assess a possible causal association. For example, the only identified RCT by Kersten et al. [98] conducted an intervention study to understand whether a reduced ADS score would improve cognition. This type of intervention study is very useful to investigate the impact of deprescribing, which can indirectly prove causal effects.

Despite the great number of validation studies, we were not able to measure the overall effect size for one of the four most investigated clinical outcomes. We encountered too much heterogeneity in terms of study design, study population and outcome measurement methods, rendering a meta-analysis impossible. So far, one study performed a meta-analysis for all-cause-mortality for the ACB scale and ARS with two studies per scale showing a tendency towards a positive association [152]. However, they also reported a significant heterogeneity in study population. Of note, it is worth mentioning that deleterious side effects of the CNS in the aging population are not solely linked to the $\mathrm{ACH}$ burden, but are probably multifactorial. ABS is one of the components to be considered when assessing the risk of CNS-related drug effects.

There are some limitations to this review. We did not search in grey literature to identify possible unpublished ABS or used other databases such as CINAHL or 
PsycINFO. However, we performed a rigorous search of the reference lists of the included studies. The quality assessment with the adapted AGREE II tool did not include the relationship of the scales with one another, which should be accounted for. Additionally, we selected only validation studies calculating the cumulative ACH burden and not studies using the medication lists to differentiate between users and non-users of ACH medication. Here we recommend the review by Mayer et al., where they distinguish the two ways of use [9]. To our understanding, calculating the cumulative $\mathrm{ACH}$ burden is the intended use of the ABS; otherwise, the scoring would be redundant. However, it is questionable whether the simple addition of the scores without considering the individual dosage and other factors such as the patient's renal function is the right approach to calculate the $\mathrm{ACH}$ burden.

Last, the combination of good and fair quality studies to assign evidence levels could have skewed the rating towards higher levels. However, only one study was rated as fair quality.

The strength of this review is its systematic approach applied from the search to the quality assessments. Though the original AGREE tool has been elaborated for guidelines and not for scales, it includes 13 quality dimensions and has been thoroughly evaluated [153]. Furthermore, the tool does not only include developmental aspects such as evidence basis but also clinical applicability and external review (here validation studies). This is the first review, which systematically assessed the quality of the ABS and their validation studies through adapted tools. Additionally, at least two researchers independently completed each step of the review process.

\section{Conclusion}

We identified 19 published ABS with their validation studies and systematically assessed their quality using adapted tools. Despite differences in quality, all ABS were recommended for use with modifications. Most ABS have been validated; yet, validation studies for newer scales are lacking, and the evaluation of the association for the four most investigated clinical outcomes showed contradicting results. There is need for good quality cohort and intervention studies comparing multiple ABS to define the best scale for clinical use and to conduct a meta-analysis for the assessment of their clinical impact.

Acknowledgements The authors would like to thank Jeanette Bock (Librarian) at the cantonal Hospital of Baden, Switzerland.

Authors' contributions $\mathrm{AL}, \mathrm{VB}, \mathrm{CC}$ and ML conceived and designed the study and analyzed the results. AL and VB performed the literature search, the studies selection and the data extraction. AL, VB, KWK and ML adapted the quality assessment tools. AL, MGC and
ML assessed the quality of the scales and AL and ML the quality of the validation studies. AL, CC and ML drafted the manuscript. VB, MGC and KWK revised the manuscript. All authors approved the final version to be submitted.

Funding Open access funding provided by University of Geneva. GSASA (Swiss Association of Public Health Administration and Hospital Pharmacists), Research project of national scope

Data availability Not applicable

\section{Compliance with ethical standards}

Conflict of interest AL was funded by AbbVie AG Switzerland to participate at the European Symposium of Clinical Pharmacy (ESCP) in October 2019 in Ljubljana, Slovenia.

Ethical approval Not applicable

Consent to participate Not applicable

Consent for publication Not applicable for participants, all authors approve this manuscript to be submitted for publication.

Presentation of work Poster presentation, ESCP Congress in Ljubljana, Slovenia, taken place October 23-25, 2019 and GSASA Congress taken place December 5-6, 2019 in Lausanne, Switzerland.

Code availability Not applicable

Open Access This article is licensed under a Creative Commons Attribution 4.0 International License, which permits use, sharing, adaptation, distribution and reproduction in any medium or format, as long as you give appropriate credit to the original author(s) and the source, provide a link to the Creative Commons licence, and indicate if changes were made. The images or other third party material in this article are included in the article's Creative Commons licence, unless indicated otherwise in a credit line to the material. If material is not included in the article's Creative Commons licence and your intended use is not permitted by statutory regulation or exceeds the permitted use, you will need to obtain permission directly from the copyright holder. To view a copy of this licence, visit http://creativecommons.org/licenses/by/4.0/.

\section{References}

1. Kersten H, Wyller TB (2014) Anticholinergic drug burden in older people's brain - How well is it measured? Basic Clin Pharmacol Toxicol 114:151-159

2. Wawruch M, Macugova A, Kostkova L, Luha J, Dukat A, Murin J, Drobna V, Wilton L, Kuzelova M (2012) The use of medications with anticholinergic properties and risk factors for their use in hospitalised elderly patients. Pharmacoepidemiol Drug Saf 21(2):170-176. https://doi.org/10.1002/pds.2169

3. Collamati A, Martone AM, Poscia A, Brandi V, Celi M, Marzetti E, Cherubini A, Landi F (2016) Anticholinergic drugs and negative outcomes in the older population: from biological plausibility to clinical evidence. Aging Clin Exp Res 28(1):25-35. https://doi. org/10.1007/s40520-015-0359-7

4. Laatikainen O, Sneck S, Bloigu R, Lahtinen M, Lauri T, Turpeinen M (2016) Hospitalizations due to adverse drug events 
in the elderly-a retrospective register study. Front Pharmacol 7: 358. https://doi.org/10.3389/fphar.2016.00358

5. Mangoni AA, Jackson SHD (2003) Age-related changes in pharmacokinetics and pharmacodynamics: basic principles and practical applications. Br J Clin Pharmacol 57(1):6-14. https://doi.org/ 10.1046/j.1365-2125.2003.02007.x

6. Villalba-Moreno AM, Alfaro-Lara ER, Perez-Guerrero MC, Nieto-Martin MD, Santos-Ramos B (2016) Systematic review on the use of anticholinergic scales in poly pathological patients. Arch Gerontol Geriatr 62:1-8. https://doi.org/10.1016/j.archger. 2015.10.002

7. Tune LE (2001) Anticholinergic effects of medication in elderly patients. J Clin Psychiatry 62(SUPPL. 22):11-14

8. Rudd KM, Raehl CL, Bond CA, Abbruscato TJ, Stenhouse AC (2005) Methods for assessing drug-related anticholinergic activity. Pharmacotherapy 25(11):1592-1601. https://doi.org/10.1592/ phco.2005.25.11.1592

9. Mayer T, Haefeli WE, Seidling HM (2015) Different methods, different results-how do available methods link a patient's anticholinergic load with adverse outcomes? Eur J Clin Pharmacol 71(11):1299-1314. https://doi.org/10.1007/s00228-015-1932-X

10. Welsh TJ, van der Wardt V, Ojo G, Gordon AL, Gladman JRF (2018) Anticholinergic drug burden tools/scales and adverse outcomes in different clinical settings: a systematic review of reviews. Drugs Aging 35(6):523-538. https://doi.org/10.1007/s40266018-0549-Z

11. Salahudeen MS, Duffull SB, Nishtala PS (2015) Anticholinergic burden quantified by anticholinergic risk scales and adverse outcomes in older people: a systematic review. BMC Geriatr 15:31. https://doi.org/10.1186/s12877-015-0029-9

12. Cardwell K, Hughes CM, Ryan C (2015) The association between anticholinergic medication burden and health related outcomes in the "Oldest Old": a systematic review of the literature. Drugs Aging 32(10):835-848. https://doi.org/10.1007/s40266-0150310-9

13. Moher D, Liberati A, Tetzlaff J, Altman DG, Group P (2009) Preferred reporting items for systematic reviews and meta-analyses: the PRISMA statement. PLoS Med 6(7):e1000097. https:// doi.org/10.1371/journal.pmed.1000097

14. AGREE Next Steps Consortium (2017), The AGREE II Instrument [Updated 2017].

15. Wells GA SB, O'Connell D, Peterson J, Welch V, Losos M The Newcastle-Ottawa Scale (NOS) for assessing the quality of nonrandomized studies in meta-analyses

16. Sterne JAC SJ, Page MJ, Elbers RG, Blencowe NS, Boutron I, Cates CJ, Cheng H-Y, Corbett MS, Eldridge SM, Hernán MA, Hopewell S, Hróbjartsson A, Junqueira DR, Jüni P, Kirkham JJ, Lasserson T, Li T, McAleenan A, Reeves BC, Shepperd S, Shrier I, Stewart LA, Tilling K, White IR, Whiting PF, Higgins JPT RoB 2: a revised tool for assessing risk of bias in randomised trials.

17. Howick J CI, Glasziou P, Greenhalgh T, Heneghan C, Liberati A, Moschetti I, Phillips B, Thornton H, Goddard O, Hodgkinson M OCEBM levels of evidence working group, the Oxford Levels of Evidence 2.

18. Team R (2019) RStudio: Integrated Development for R. RStudio, Boston

19. Team RC (2019) R: A language and environment for statistical computing. R Foundation for Statistical Computing, Vienna

20. Ognyanova K (2019) Network visualization with R.

21. Wickham H (2016) ggplot2: Elegant Graphics for Data Analysis. Springer-Verlag, New York

22. Gamer M, Lemon J, Singh IFP (2012) irr: Various coefficients of interrater reliability and agreement. R package version 0.84.1.

23. Ancelin ML, Artero S, Portet F, Dupuy AM, Touchon J, Ritchie K (2006) Non-degenerative mild cognitive impairment in elderly people and use of anticholinergic drugs: longitudinal cohort study.
Bmj 332(7539):455-459. https://doi.org/10.1136/bmj.38740. 439664.DE

24. Bishara D, Harwood D, Sauer J, Taylor DM (2017) Anticholinergic effect on cognition (AEC) of drugs commonly used in older people. Int J Geriatr Psychiatry 32(6):650-656. https://doi.org/10.1002/gps.4507

25. Boustani M, Campbell N, Munger S, Maidment I, Fox C (2008) Impact of anticholinergics on the aging brain: a review and practical application. Aging Health 4(3):311-320. https://doi.org/10. 2217/1745509x.4.3.311

26. Briet J, Javelot H, Heitzmann E, Weiner L, Lameira C, D'Athis P, Corneloup M, Vailleau JL (2017) The anticholinergic impregnation scale: Towards the elaboration of a scale adapted to prescriptions in French psychiatric settings. Therapie 72(4):427-437. https://doi.org/10.1016/j.therap.2016.12.010

27. Campbell NL, Maidment I, Fox C, Khan B, Boustani M (2013) The 2012 update to the anticholinergic cognitive burden scale. J Am Geriatr Soc 61:S142-S143. https://doi.org/10.1111/jgs.12263

28. Cancelli I, Valentinis L, Merlino G, Valente M, Gigli GL (2008) Drugs with anticholinergic properties as a risk factor for psychosis in patients affected by Alzheimer's disease. Clin Pharmacol Ther 84(1):63-68. https://doi.org/10.1038/sj.clpt.6100435

29. Carnahan RM, Lund BC, Perry PJ, Culp KR, Pollock BG (2002) The relationship of an anticholinergic rating scale with serum anticholinergic activity in elderly nursing home residents. Psychopharmacol Bull 36(4):14-19

30. Carnahan RM, Lund BC, Perry PJ, Pollock BG, Culp KR (2006) The anticholinergic drug scale as a measure of drug-related anticholinergic burden: associations with serum anticholinergic activity. J Clin Pharmacol 46(12):1481-1486. https://doi.org/10.1177/ 0091270006292126

31. Chew ML, Mulsant BH, Pollock BG, Lehman ME, Greenspan A, Mahmoud RA, Kirshner MA, Sorisio DA, Bies RR, Gharabawi G (2008) Anticholinergic activity of 107 medications commonly used by older adults. J Am Geriatr Soc 56(7):1333-1341. https:// doi.org/10.1111/j.1532-5415.2008.01737.x

32. Duran CE, Azermai M, Vander Stichele RH (2013) Systematic review of anticholinergic risk scales in older adults. Eur J Clin Pharmacol 69(7):1485-1496. https://doi.org/10.1007/s00228013-1499-3

33. Ehrt U, Broich K, Larsen JP, Ballard C, Aarsland D (2010) Use of drugs with anticholinergic effect and impact on cognition in Parkinson's disease: a cohort study. J Neurol Neurosurg Psychiatry 81(2):160-165. https://doi.org/10.1136/jnnp.2009. 186239

34. Han L, Agostini JV, Allore HG (2008) Cumulative anticholinergic exposure is associated with poor memory and executive function in older men. J Am Geriatr Soc 56(12):2203-2210. https://doi.org/ 10.1111/j.1532-5415.2008.02009.x

35. Han L, McCusker J (2001) Use of medications with anticholinergic effect predicts clinical severity of delirium symptoms in older medical inpatients. Arch Intern Med 161:1099-1105

36. Hefner G, Shams M, K W-S (2015) Rating the delirogenic potential of drugs for prediction of side effects in elderly psychiatric inpatients. J J Pharma Pharmacovigilance 1(003)

37. Jun K, Hwang S, Ah YM, Suh Y, Lee JY (2019) Development of an anticholinergic burden scale specific for Korean older adults. Geriatr Gerontol Int. https://doi.org/10.1111/ggi.13680

38. Kiesel EK, Hopf YM, Drey M (2018) An anticholinergic burden score for German prescribers: score development. BMC Geriatr 18(1):239. https://doi.org/10.1186/s12877-018-0929-6

39. Minzenberg MJ, Poole JH, Benton C, Vinogradov S (2004) Association of anticholinergic load with impairment of complex attention and memory in schizophrenia. Am J Psychiatry 161(1): 116-124. https://doi.org/10.1176/appi.ajp.161.1.116 
40. Nery RT, Reis AMM (2019) Development of a Brazilian anticholinergic activity drug scale. Einstein (Sao Paulo, Brazil) 17(2): eAO4435. https://doi.org/10.31744/einstein_journal/ 2019AO4435

41. Rudolph JS, Angelini MC (2008) The anticholinergic risk scale and anticholinergic adverse effects in older persons. Arch Intern Med 168(5):508-513

42. Sittironnarit G, Ames D, Bush AI, Faux N, Flicker L, Foster J, Hilmer S, Lautenschlager NT, Maruff P, Masters CL, Martins RN, Rowe C, Szoeke C, Ellis KA (2011) Effects of anticholinergic drugs on cognitive function in older Australians: results from the AIBL study. Dement Geriatr Cogn Disord 31(3):173-178. https:// doi.org/10.1159/000325171

43. Summers KW (1978) A clinical method of estimating risk of druc induced delirium. Life Sci 22:1511-1516

44. Xu D, Anderson HD, Tao A, Hannah KL, Linnebur SA, Valuck RJ, Culbertson VL (2017) Assessing and predicting drug-induced anticholinergic risks: an integrated computational approach. Ther Adv Drug Saf 8(11):361-370. https://doi.org/10.1177/ 2042098617725267

45. Aizenberg D, Sigler M, Weizman A, Barak Y (2002) Anticholinergic burden and the risk of falls among elderly psychiatric inpatients: a 4-year case-control study. Int Psychogeriatr 14(3):307-310

46. Whalley LJ, Sharma S, Fox HC, Murray AD, Staff RT, Duthie AC, Deary IJ, Starr JM (2012) Anticholinergic drugs in late life: adverse effects on cognition but not on progress to dementia. J Alzheimers Dis 30(2):253-261. https://doi.org/10.3233/jad-2012110935

47. Hilmer SN, Mager DE, Simonsick EM, Ling SM, Windham BG, Harris TB, Shorr RI, Bauer DC, Abernethy DR, Health ABCS (2007) A drug burden index to define the functional burden of medications in older people. Arch Intern Med 167:781-787

48. Hilmer SN, Mager DE, Simonsick EM, Ling SM, Windham BG, Harris TB, Shorr RI, Bauer DC, Abernethy DR, Health ABCS (2009) Drug burden index score and functional decline in older people. Am J Med 122(12):1142-1149 e1141-1142. https://doi. org/10.1016/j.amjmed.2009.02.021

49. Nguyen PV-Q, Pelletier L, Payot I, Latour J (2018) The Delirium Drug Scale is associated to delirium incidence in the emergency department. Int Psychogeriatr 30(4):503-510. https://doi.org/10. 1017/s1041610217002538

50. Cao YJ, Mager DE, Simonsick EM, Hilmer SN, Ling SM, Windham BG, Crentsil V, Yasar S, Fried LP, Abernethy DR (2008) Physical and cognitive performance and burden of anticholinergics, sedatives, and ACE inhibitors in older women. Clin Pharmacol Ther 83(3):422-429. https://doi.org/10.1038/sj.clpt. 6100303

51. Klamer TT, Wauters M, Azermai M, Duran C, Christiaens T, Elseviers M, Vander Stichele R (2017) A novel scale linking potency and dosage to estimate anticholinergic exposure in older adults: the Muscarinic acetylcholinergic receptor ANTagonist exposure scale. Basic Clin Pharmacol Toxicol 120(6):582-590. https://doi.org/10.1111/bcpt.12699

52. Naples JG, Marcum ZA, Perera S, Gray SL, Newman AB, Simonsick EM, Yaffe K, Shorr RI, Hanlon JT, Health A, Body Composition S (2015) Concordance between anticholinergic burden scales. J Am Geriatr Soc 63(10):2120-2124. https://doi.org/ 10.1111 /jgs. 13647

53. Ablett AD, Wood AD, Barr R, Guillot J, Black AJ, Macdonald HM, Reid DM, Myint PK (2018) A high anticholinergic burden is associated with a history of falls in the previous year in middleaged women: findings from the Aberdeen Prospective Osteoporosis Screening Study. Ann Epidemiol 28(8):557562.e552. https://doi.org/10.1016/j.annepidem.2018.05.011
54. Agar M, Currow D, Plummer J, Seidel R, Carnahan R, Abernethy AP (2009) Changes in anticholinergic load from regular prescribed medications in palliative care as death approaches. Palliat Med 23(3):257-265. https://doi.org/10.1177/ 0269216309102528

55. Ah YM, Suh Y, Jun K, Hwang S, Lee JY (2019) Effect of anticholinergic burden on treatment modification, delirium and mortality in newly diagnosed dementia patients starting a cholinesterase inhibitor: a population-based study. Basic Clin Pharmacol Toxicol 124:741-748. https://doi.org/10.1111/bcpt.13184

56. Aldebert G, Faillie J-L, Hillaire-Buys D, Mura T, Carriere I, Delcourt C, Creuzot-Garcher C, Villain M, Daien V (2018) Association of Anticholinergic Drug Use With Risk for Late Age-Related Macular Degeneration. JAMA Ophthalmol 136(7): 770-778. https://doi.org/10.1001/jamaophthalmol.2018.1719

57. Andre L, Gallini A, Montastruc F, Coley N, Montastruc J-L, Vellas B, Andrieu S, Gardette V, Grp MDS (2019) Anticholinergic exposure and cognitive decline in older adults: effect of anticholinergic exposure definitions in a 3-year analysis of the multidomain Alzheimer preventive trial (MAPT) study. Br J Clin Pharmacol 85(1):71-99. https://doi.org/10.1111/bcp.13734

58. Ang MS, Abdul Rashid NA, Lam M, Rapisarda A, Kraus M, Keefe RSE, Lee J (2017) The impact of medication anticholinergic burden on cognitive performance in people with schizophrenia. J Clin Psychopharmacol 37(6):651-656. https://doi.org/10. 1097/jcp.0000000000000790

59. Block CK, Logue E, Thaler NS, Scarisbrick DM, Mahoney JJ 3rd, Scott J, Duff K (2015) The interaction between medical burden and anticholinergic cognitive burden on neuropsychological function in a geriatric primary care sample. Arch Clin Neuropsychol 30(2):105-113. https://doi.org/10.1093/arclin/acu073

60. Bostock CV, Soiza RL, Mangoni AA (2013) Associations between different measures of anticholinergic drug exposure and Barthel Index in older hospitalized patients. Ther Adv Drug Saf 4(6):235-245. https://doi.org/10.1177/2042098613500689

61. Brombo G, Bianchi L, Maietti E, Malacarne F, Corsonello A, Cherubini A, Ruggiero C, Onder G, Volpato S (2018) Association of anticholinergic drug burden with cognitive and functional decline over time in older inpatients: results from the CRIME project. Drugs Aging 35(10):917-924. https://doi.org/10. 1007/s40266-018-0584-9

62. Burry LD, Williamson DR, Mehta S, Perreault MM, Mantas I, Mallick R, Fergusson DA, Smith O, Fan E, Dupuis S, Herridge M, Rose L (2017) Delirium and exposure to psychoactive medications in critically ill adults: A multi-centre observational study. J Crit Care 42:268-274. https://doi.org/10.1016/j.jcrc.2017.08.003

63. Campbell NL, Boustani MA, Lane KA, Gao S, Hendrie H, Khan BA, Murrell JR, Unverzagt FW, Hake A, Smith-Gamble V, Hall $\mathrm{K}$ (2010) Use of anticholinergics and the risk of cognitive impairment in an African American population. Neurology 75(2):152159. https://doi.org/10.1212/WNL.0b013e3181e7f2ab

64. Campbell NL, Lane KA, Gao S, Boustani MA, Unverzagt F (2018) Anticholinergics influence transition from normal cognition to mild cognitive impairment in older adults in primary care. Pharmacotherapy 38(5):511-519. https://doi.org/10.1002/phar. 2106

65. Campbell NL, Perkins A, Hui S, Khan B, Boustani M (2011) Association between prescribing of anticholinergic medications and incident delirium: a cohort study. J Am Geriatr Soc 59(Supp1 2):S277-S281. https://doi.org/10.1111/j.1532-5415. 2011.03676.x

66. Campbell NL, Perkins AJ, Bradt P, Perk S, Wielage RC, Boustani MA, Ng DB (2016) Association of anticholinergic burden with cognitive impairment and health care utilization among a diverse ambulatory older adult population. Pharmacotherapy 36(11): 1123-1131. https://doi.org/10.1002/phar.1843 
67. Chatterjee S, Bali V, Carnahan RM, Chen H, Johnson ML, Aparasu RR (2016) Anticholinergic medication use and risk of fracture in elderly adults with depression. J Am Geriatr Soc 64(7): 1492-1497. https://doi.org/10.1111/jgs. 14182

68. Chatterjee S, Bali V, Carnahan RM, Chen H, Johnson ML, Aparasu RR (2017) Risk of mortality associated with anticholinergic use in elderly nursing home residents with depression. Drugs Aging 34(9):691-700. https://doi.org/10.1007/s40266-017-04755

69. Chatterjee S, Bali V, Carnahan RM, Johnson ML, Chen H, Aparasu RR (2016) Anticholinergic medication use and risk of dementia among elderly nursing home residents with depression. Am J Geriatr Psychiatry 24(6):485-495. https://doi.org/10.1016/j. jagp.2015.12.011

70. Clark K, Lam LT, Agar M, Chye R, Currow DC (2010) The impact of opioids, anticholinergic medications and disease progression on the prescription of laxatives in hospitalized palliative care patients: a retrospective analysis. Palliat Med 24(4):410-418. https://doi.org/10.1177/0269216310363649

71. Clarke CL, Sniehotta FF, Vadiveloo T, Donnan PT, Witham MD (2018) Association between objectively measured physical activity and opioid, hypnotic, or anticholinergic medication use in older people: data from the physical activity cohort scotland study. Drugs Aging 35(9):835-842. https://doi.org/10.1007/s40266018-0578-7

72. Corsonello A, Cozza A, D'Alia S, Onder G, Volpato S, Ruggiero C, Cherubini A, Di Rosa M, Fabbietti P, Lattanzio F (2019) The excess mortality risk associated with anticholinergic burden among older patients discharged from acute care hospital with depressive symptoms. Eur J Intern Med 61:69-74. https://doi. org/10.1016/j.ejim.2018.11.004

73. Cossette B, Bagna M, Sene M, Sirois C, Lefebvre GP, Germain O, Morais JA, Gaudreau P, Payette H (2017) Association between anticholinergic drug use and health-related quality of life in community-dwelling older adults. Drugs Aging 34(10):785-792. https://doi.org/10.1007/s40266-017-0486-2

74. Crispo JAG, Willis AW, Thibault DP, Fortin Y, Hays HD, McNair DS, Bjerre LM, Kohen DE, Perez-Lloret S, Mattison DR, Krewski D (2016) Associations between anticholinergic burden and adverse health outcomes in parkinson disease. PLoS One 11(3):e0150621. https://doi.org/10.1371/journal.pone.0150621

75. Cross AJ, George J, Woodward MC, Ames D, Brodaty H, Wolfe R, Connors MH, Elliott RA (2017) Potentially inappropriate medication, anticholinergic burden, and mortality in people attending memory clinics. J Alzheimers Dis 60(2):349-358. https://doi.org/ 10.3233/jad-170265

76. Dauphinot V, Mouchoux C, Veillard S, Delphin-Combe F, Krolak-Salmon P (2017) Anticholinergic drugs and functional, cognitive impairment and behavioral disturbances in patients from a memory clinic with subjective cognitive decline or neurocognitive disorders. Alzheimers Res Ther 9:58. https://doi. org/10.1186/s13195-017-0284-4

77. De La Cruz JF, Kisby C, Wu JM, Geller EJ (2015) Impact of anticholinergic load on bladder function. Int Urogynecol J 26(4): 545-549. https://doi.org/10.1007/s00192-014-2548-x

78. Dispennette R, Elliott D, Nguyen L, Richmond R (2014) Drug Burden Index score and anticholinergic risk scale as predictors of readmission to the hospital. Consult Pharm 29(3):158-168. https://doi.org/10.4140/TCP.n.2014.158

79. Drag LL, Wright SL, Bieliauskas LA (2012) Prescribing practices of anticholinergic medications and their association with cognition in an extended care setting. J Appl Gerontol 31(2):239-259. https://doi.org/10.1177/0733464810384592

80. Egberts A, van der Craats ST, van Wijk MD, Alkilabe S, van den Bemt PMLA, Mattace-Raso FUS (2017) Anticholinergic drug exposure is associated with delirium and postdischarge institutionalization in acutely ill hospitalized older patients. Pharmacol Res Perspect 5(3). https://doi.org/10.1002/prp2.310

81. Ellett LMK, Pratt NL, Ramsay EN, Barratt JD, Roughead EE (2014) Multiple anticholinergic medication use and risk of hospital admission for confusion or dementia. J Am Geriatr Soc 62(10): 1916-1922. https://doi.org/10.1111/jgs.13054

82. Eum S, Hill K, Rubin LH, Carnahan RM, Reilly JL, Ivleva EI, Keedy SK, Tamminga CA, Pearlson GD, Clementz BA, Gershong ES, Keshavan MS, Keefe RSE, Sweeney JA, Bishop JR (2017) Cognitive burden of anticholinergic medications in psychotic disorders. Schizophr Res 190:129-135. https://doi.org/10. 1016/j.schres.2017.03.034

83. Fox C, Livingston G, Maidment ID, Coulton S, Smithard DG, Boustani M, Katona C (2011) The impact of anticholinergic burden in Alzheimer's dementia-the LASER-AD study. Age Ageing 40(6):730-735. https://doi.org/10.1093/ageing/afr102

84. Fox C, Richardson K, Maidment ID, Savva GM, Matthews FE, Smithard D, Coulton S, Katona C, Boustani MA, Brayne C (2011) Anticholinergic medication use and cognitive impairment in the older population: the medical research council cognitive function and ageing study. J Am Geriatr Soc 59(8):1477-1483. https://doi. org/10.1111/j.1532-5415.2011.03491.x

85. Gamble DT, Clark AB, Luben RN, Wareham NJ, Khaw KT, Myint PK (2018) Baseline anticholinergic burden from medications predicts incident fatal and non-fatal stroke in the EPICNorfolk general population. Int J Epidemiol 47(2):625-633. https://doi.org/10.1093/ije/dyx265

86. Gouraud-Tanguy A, Berlioz-Thibal M, Brisseau J-M, Aoudia VO, Beauchet O, Berrut G, De Decker L (2012) Analysis of iatrogenic risk related to anticholinergic effects using two scales in acute geriatric inpatient unit. Geriatr Psychol Neuropsychiatr Vieil 10(1):27-32. https://doi.org/10.1684/pnv.2012.0337

87. Green AR, Reifler LM, Bayliss EA, Weffald LA, Boyd CM (2019) Drugs contributing to anticholinergic burden and risk of fall or fall-related injury among older adults with mild cognitive impairment, dementia and multiple chronic conditions: a retrospective cohort study. Drugs Aging 36(3):289-297. https://doi. org/10.1007/s40266-018-00630-Z

88. Gupte KP, Wu W (2015) Impact of anticholinergic load of medications on the length of stay of cancer patients in hospice care. Int J Pharm Pract 23(3):192-198. https://doi.org/10.1111/ijpp.12132

89. Gutierrez-Valencia M, Martinez-Velilla N, Liborio Vetrano D, Corsonello A, Lattanzio F, Ladron-Arana S, Onder G (2017) Anticholinergic burden and health outcomes among older adults discharged from hospital: results from the CRIME study. Eur $\mathrm{J}$ Clin Pharmacol 73(11):1467-1474. https://doi.org/10.1007/ s00228-017-2312-5

90. Hochman MJ, Kamal AH, Wolf SP, Samsa GP, Currow DC, Abernethy AP, LeBlanc TW (2016) Anticholinergic drug burden in noncancer versus cancer patients near the end of life. J Pain Symptom Manage 52(5):737. https://doi.org/10.1016/j. jpainsymman.2016.03.020

91. Hsu W-H, Wen Y-W, Chen L-K, Hsiao F-Y (2017) Comparative associations between measures of anti-cholinergic burden and adverse clinical outcomes. Ann Fam Med 15(6):561-569. https:// doi.org/10.1370/afm.2131

92. Jaidi Y, Guilloteau A, Nonnonhou V, Bertholon L-A, Badr S, Morrone I, Novella J-L, Mahmoudi R (2019) Threshold for a reduction in anticholinergic burden to decrease behavioral and psychological symptoms of dementia. J Am Med Dir Assoc 20(2):159. https://doi.org/10.1016/j.jamda.2018.10.015

93. Jean-Bart E, Moutet C, Dauphinot V, Krolak-Salmon P, Mouchoux C (2017) Exposure to anticholinergic and sedative medicines as indicators of high-risk prescriptions in the elderly. Int J Clin Pharm 39(6):1237-1247. https://doi.org/10.1007/ s11096-017-0533-4 
94. Jessen F, Kaduszkiewicz H, Daerr M, Bickel H, Pentzek M, Riedel-Heller S, Wagner M, Weyerer S, Wiese B, van den Bussche H, Broich K, Maier W (2010) Anticholinergic drug use and risk for dementia: target for dementia prevention. Eur Arch Psychiatry Clin Neurosci 260:S111-S115. https://doi.org/10. 1007/s00406-010-0156-4

95. Joshi YB, Thomas ML, Hochberger WC, Bismark AW, Treichler EBH, Molina J, Nungaray J, Cardoso L, Sprock J, Swerdlow NR, Light GA (2019) Verbal learning deficits associated with increased anticholinergic burden are attenuated with targeted cognitive training in treatment refractory schizophrenia patients. Schizophr Res 208:384-389. https://doi.org/10.1016/j.schres. 2019.01.016

96. Juliebo V, Bjoro K, Krogseth M, Skovlund E, Ranhoff AH, Wyller TB (2009) Risk factors for preoperative and postoperative delirium in elderly patients with hip fracture. J Am Geriatr Soc 57(8):1354-1361. https://doi.org/10.1111/j.1532-5415.2009. 02377.x

97. Kashyap M, Belleville S, Mulsant BH, Hilmer SN, Paquette A, Tu LM, Tannenbaum C (2014) Methodological challenges in determining longitudinal associations between anticholinergic drug use and incident cognitive decline. J Am Geriatr Soc 62(2):336-341. https://doi.org/10.1111/jgs.12632

98. Kersten H, Molden E, Tolo IK, Skovlund E, Engedal K, Wyller TB (2013) Cognitive effects of reducing anticholinergic drug burden in a frail elderly population: a randomized controlled trial. J Gerontol A Biol Sci Med Sci 68(3):271-278. https://doi.org/10. 1093/gerona/gls176

99. Kersten H, Molden E, Willumsen T, Engedal K, Wyller TB (2013) Higher anticholinergic drug scale (ADS) scores are associated with peripheral but not cognitive markers of cholinergic blockade. Cross sectional data from 21 Norwegian nursing homes. Br J Clin Pharmacol 75(3):842-849. https://doi.org/10.1111/j. 1365-2125.2012.04411.x

100. Kidd AC, Musonda P, Soiza RL, Butchart C, Lunt CJ, Pai Y, Hameed Y, Fox C, Potter JF, Myint PK (2014) The relationship between total anticholinergic burden (ACB) and early in-patient hospital mortality and length of stay in the oldest old aged 90 years and over admitted with an acute illness. Arch Gerontol Geriatr 59(1):155-161. https://doi.org/10.1016/j.archger.2014.01.006

101. Kolanowski A, Fick DM, Campbell J, Litaker M, Boustani M (2009) A Preliminary study of anticholinergic burden and relationship to a quality of life indicator, engagement in activities, in nursing home residents with dementia. J Am Med Dir Assoc 10(4):252-257. https://doi.org/10.1016/j.jamda.2008.11.005

102. Kose E, Hirai T, Seki T (2018) Anticholinergic drugs use and risk of hip fracture in geriatric patients. Geriatr Gerontol Int 18(9): 1340-1344. https://doi.org/10.1111/ggi.13486

103. Kose E, Hirai T, Seki T (2018) Assessment of aspiration pneumonia using the Anticholinergic Risk Scale. Geriatr Gerontol Int 18(8):1230-1235. https://doi.org/10.1111/ggi.13454

104. Kose E, Hirai T, Seki T, Hidaka S, Hamamoto T (2018) Anticholinergic load negatively correlates with recovery of cognitive activities of daily living for geriatric patients after stroke in the convalescent stage. J Clin Pharm Ther 43(6):799-806. https:// doi.org/10.1111/jept.12706

105. Koshoedo S, Soiza RL, Purkayastha R, Mangoni AA (2012) Anticholinergic drugs and functional outcomes in older patients undergoing orthopaedic rehabilitation. Am J Geriatr Pharmacother 10(4):251-257. https://doi.org/10.1016/j. amjopharm.2012.06.003

106. Koyama A, Steinman M, Ensrud K, Hillier TA, Yaffe K (2013) Ten-year trajectory of potentially inappropriate medications in very old women: importance of cognitive status. J Am Geriatr Soc 61(2):258-263. https://doi.org/10.1111/jgs.12093
107. Koyama A, Steinman M, Ensrud K, Hillier TA, Yaffe K (2014) Long-term cognitive and functional effects of potentially inappropriate medications in older women. J Gerontol A Biol Sci Med Sci 69(4):423-429. https://doi.org/10.1093/gerona/glt192

108. Kumpula E-K, Bell JS, Soini H, Pitkala KH (2011) Anticholinergic drug use and mortality among residents of long-term care facilities: a prospective cohort study. J Clin Pharmacol 51(2):256-263. https://doi.org/10.1177/ 0091270010368410

109. Lampela P, Lavikainen P, Garcia-Horsman JA, Bell JS, Huupponen R, Hartikainen S (2013) Anticholinergic drug use, serum anticholinergic activity, and adverse drug events among older people: a population-based study. Drugs Aging 30(5): 321-330. https://doi.org/10.1007/s40266-013-0063-2

110. Lampela P, Tolppanen A-M, Tanskanen A, Tiihonen J, Hartikainen S, Taipale H (2017) Anticholinergic exposure and risk of pneumonia in persons with Alzheimer's disease: a nested case-control study. J Alzheimers Dis 56(1):119-128. https://doi. org/10.3233/jad-160956

111. Lanctot KL, O'Regan J, Schwartz Y, Swardfager W, Saleem M, Oh PI, Herrmann N (2014) Assessing cognitive effects of anticholinergic medications in patients with coronary artery disease. Psychosomatics 55(1):61-68

112. Landi F, Dell'Aquila G, Collamati A, Martone AM, Zuliani G, Gasperini B, Eusebi P, Lattanzio F, Cherubini A (2014) Anticholinergic drug use and negative outcomes among the frail elderly population living in a nursing home. J Am Med Dir Assoc 15(11):825-829. https://doi.org/10.1016/j.jamda.2014.08.002

113. Lattanzio F, Corica F, Schepisi R, Amantea D, Bruno F, Cozza A, Onder G, Volpato S, Cherubini A, Ruggiero C, Maggio MG, Corsonello A (2018) Anticholinergic burden and 1-year mortality among older patients discharged from acute care hospital. Geriatr Gerontol Int 18:705-713. https://doi.org/10.1111/ggi.13234

114. Low LF, Anstey KJ, Sachdev P (2009) Use of medications with anticholinergic properties and cognitive function in a young-old community sample. Int J Geriatr Psychiatry 24(6):578-584. https://doi.org/10.1002/gps.2157

115. Lowry E, Woodman RJ, Soiza RL, Mangoni AA (2011) Associations between the anticholinergic risk scale score and physical function: potential implications for adverse outcomes in older hospitalized patients. J Am Med Dir Assoc 12(8):565572. https://doi.org/10.1016/j.jamda.2011.03.006

116. Lowry E, Woodman RJ, Soiza RL, Mangoni AA (2011) Clinical and demographic factors associated with antimuscarinic medication use in older hospitalized patients. Hosp Pract (1995) 39(1): 30-36. https://doi.org/10.3810/hp.2011.02.371

117. Lu WH, Wen YW, Chen LK, Hsiao FY (2015) Effect of polypharmacy, potentially inappropriate medications and anticholinergic burden on clinical outcomes: a retrospective cohort study. CMAJ 187(4):E130-E137. https://doi.org/10.1503/cmaj.141219

118. Machado-Duque ME, Pablo Castano-Montoya J, Medina-Morales DA, Castro-Rodriguez A, Gonzalez-Montoya A, Machado-Alba JE (2018) Drugs with anticholinergic potential and risk of falls with hip fracture in the elderly patients: a case-control study. J Geriatr Psychiatry Neurol 31(2):63-69. https://doi.org/10.1177/ 0891988718757370

119. Mangoni AA, Kim S, Hakendorf P, Mayner L, Woodman RJ (2016) Heat waves, drugs with anticholinergic effects, and outcomes in older hospitalized adults. J Am Geriatr Soc 64(5):10911096. https://doi.org/10.1111/jgs. 14100

120. Mangoni AA, van Munster BC, Woodman RJ, de Rooij SE (2013) Measures of anticholinergic drug exposure, serum anticholinergic activity, and all-cause postdischarge mortality in older hospitalized patients with hip fractures. Am J Geriatr Psychiatry 21(8): 785-793. https://doi.org/10.1016/j.jagp.2013.01.012 
121. Mayer T, Meid AD, Saum K-U, Brenner H, Schoettker B, Seidling HM, Haefeli WE (2017) Comparison of nine instruments to calculate anticholinergic load in a large cohort of older outpatients: association with cognitive and functional decline, falls, and use of laxatives. Am J Geriatr Psychiatry 25(5):531-540. https:// doi.org/10.1016/j.jagp.2017.01.009

122. Moulis F, Moulis G, Balardy L, Gerard S, Montastruc F, Sourdet S, Rouge-Bugat M-E, Lapeyre-Mestre M, Montastruc J-L, Rolland Y, Vellas B (2015) Exposure to atropinic drugs and frailty status. J Am Med Dir Assoc 16(3):253-257. https://doi.org/10. 1016/j.jamda.2014.11.017

123. Myint PK, Fox C, Kwok CS, Luben RN, Wareham NJ, Khaw K-T (2015) Total anticholinergic burden and risk of mortality and cardiovascular disease over 10 years in 21,636 middle-aged and older men and women of EPIC-Norfolk prospective population study. Age Ageing 44(2):219-225. https://doi.org/10.1093/ageing/ afu185

124. Naharci MI, Cintosun U, Ozturk A, Oztin H, Turker T, Bozoglu E, Doruk H (2017) Effect of anticholinergic burden on the development of dementia in older adults with subjective cognitive decline. Psychiatr Clin Psychopharmacol 27(3):269-276. https://doi.org/ 10.1080/24750573.2017.1358130

125. O'Dwyer M, Maidment ID, Bennett K, Peklar J, Mulryan N, McCallion P, McCarron M, Henman MC (2016) Association of anticholinergic burden with adverse effects in older people with intellectual disabilities: an observational cross-sectional study. $\mathrm{Br}$ J Psychiatry 209(6):504-510. https://doi.org/10.1192/bjp.bp.115. 173971

126. Pasina L, Colzani L, Cortesi L, Tettamanti M, Zambon A, Nobili A, Mazzone A, Mazzola P, Annoni G, Bellelli G (2019) Relation between delirium and anticholinergic drug burden in a cohort of hospitalized older patients: an observational study. Drugs Aging 36(1):85-91. https://doi.org/10.1007/s40266-018-0612-9

127. Pasina L, Djade CD, Lucca U, Nobili A, Tettamanti M, Franchi C, Salerno F, Corrao S, Marengoni A, Iorio A, Marcucci M, Violi F, Mannucci PM (2013) Association of anticholinergic burden with cognitive and functional status in a cohort of hospitalized elderly: comparison of the anticholinergic cognitive burden scale and anticholinergic risk scale: results from the REPOSI study. Drugs Aging 30(2):103-112. https://doi.org/10.1007/s40266-012-0044$\mathrm{x}$

128. Pfistermeister B, Tumena T, Gassmann KG, Maas R, Fromm MF (2017) Anticholinergic burden and cognitive function in a large German cohort of hospitalized geriatric patients. PLoS One 12(2): e0171353. https://doi.org/10.1371/journal.pone.0171353

129. Richardson K, Bennett K, Maidment ID, Fox C, Smithard D, Kenny RA (2015) Use of medications with anticholinergic activity and self-reported injurious falls in older community-dwelling adults. J Am Geriatr Soc 63(8):1561-1569. https://doi.org/10. 1111 /jgs. 13543

130. Richardson K, Fox C, Maidment I, Steel N, Loke YK, Arthur A, Myint PK, Grossi CM, Mattishent K, Bennett K, Campbell NL, Boustani M, Robinson L, Brayne C, Matthews FE, Savva GM (2018) Anticholinergic drugs and risk of dementia: case-control study. Bmj 361:k1315. https://doi.org/10.1136/bmj.k1315

131. Salahudeen MS, Hilmer SN, Nishtala PS (2015) Comparison of anticholinergic risk scales and associations with adverse health outcomes in older people. J Am Geriatr Soc 63(1):85-90. https:// doi.org/10.1111/jgs.13206

132. Sarbacker GB, Espino DV, Wood RC, Oakes SL, Anand D, Markides KA (2017) Total anticholinergic burden and survival within a cohort of elderly Mexican Americans. Geriatr Gerontol Int 17(10):1515-1521. https://doi.org/10.1111/ggi.12907

133. Sevilla-Sanchez D, Molist-Brunet N, Amblas-Novellas J, RouraPoch P, Espaulella-Panicot J, Codina-Jane C (2017) Adverse drug events in patients with advanced chronic conditions who have a prognosis of limited life expectancy at hospital admission. Eur J Clin Pharmacol 73(1):79-89. https://doi.org/10.1007/s00228016-2136-8

134. Sevilla-Sanchez D, Molist-Brunet N, Gonzalez-Bueno J, SolaBonada N, Espaulella-Panicot J, Codina-Jane C (2018) Prevalence, risk factors and adverse outcomes of anticholinergic burden in patients with advanced chronic conditions at hospital admission. Geriatr Gerontol Int 18(8):1159-1165. https://doi.org/ 10.1111/ggi.13330

135. Sheehan C, Clark K, Lam L, Chye R (2011) A retrospective analysis of primary diagnosis, comorbidities, anticholinergic load, and other factors on treatment for noisy respiratory secretions at the end of life. J Palliat Med 14(11):1211-1216. https://doi.org/10. 1089/jpm.2011.0191

136. Szabo SM, Gooch K, Schermer C, Walker D, Lozano-Ortega G, Rogula B, Deighton A, Vonesh E, Campbell N (2019) Association between cumulative anticholinergic burden and falls and fractures in patients with overactive bladder: US-based retrospective cohort study. BMJ Open 9(5):e026391. https://doi.org/10.1136/bmjopen2018-026391

137. Tan ECK, Eriksdotter M, Garcia-Ptacek S, Fastbom J, Johnell K (2018) Anticholinergic burden and risk of stroke and death in people with different types of dementia. J Alzheimers Dis 65(2): 589-596. https://doi.org/10.3233/JAD-180353

138. Teramura-Gronblad M, Muurinen S, Soini H, Suominen M, Pitkala KH (2011) Use of anticholinergic drugs and cholinesterase inhibitors and their association with psychological well-being among frail older adults in residential care facilities. Ann Pharmacother 45(5):596-602. https://doi.org/10.1345/aph.1P650

139. Tiisanoja A, Syrjala A-M, Komulainen K, Lampela P, Hartikainen S, Taipale H, Knuuttila M, Ylostalo P (2018) Anticholinergic burden and dry mouth among Finnish, community-dwelling older adults. Gerodontology 35(1):3-10. https://doi.org/10.1111/ger. 12304

140. Tsoutsoulas C, Mulsant BH, Kumar S, Ghazala Z, Voineskos AN, Menon M, Pollock BG, Rajji TK (2017) Anticholinergic burden and cognition in older patients with schizophrenia. J Clin Psychiatry 78(9):E1284-E1290. https://doi.org/10.4088/JCP. $17 \mathrm{~m} 11523$

141. Vetrano DL, La Carpia D, Grande G, Casucci P, Bacelli T, Bernabei R, Onder G (2016) Anticholinergic medication burden and 5-year risk of hospitalization and death in nursing home elderly residents with coronary artery disease. J Am Med Dir Assoc 17(11):1056-1059. https://doi.org/10.1016/j.jamda.2016.07.012

142. Walter PJ, Dieter AA, Siddiqui NY, Weidner AC, Wu JM (2014) Perioperative anticholinergic medications and risk of catheterization after urogynecologic surgery. Female Pelvic Med Reconstr Surg 20(3):163-167. https://doi.org/10.1097/spv. 0000000000000075

143. Weglinski L, Manceau P, Thomas-Pohl M, Le Breton F, Amarenco G (2017) Prospective evaluation of mouth and eye dryness induced by antimuscarinic drugs used for neurogenic overactive bladder in 35 patients with multiple sclerosis. Progres En Urologie 27(4):253-260. https://doi.org/10.1016/j.purol.2016. 10.005

144. Wolters AE, Zaal IJ, Veldhuijzen DS, Cremer OL, Devlin JW, van Dijk D, Slooter AJC (2015) Anticholinergic medication use and transition to delirium in critically ill patients: a prospective cohort study. Crit Care Med 43(9):1846-1852. https://doi.org/10.1097/ ccm.0000000000001094

145. Yarnall AJ, Lawson RA, Duncan GW, Breen DP, Khoo TK, Brooks D, Barker RA, Taylor J-P, Burn DJ (2015) Anticholinergic load: is there a cognitive cost in early Parkinson's disease? J Parkinsons Dis 5(4):743-747. https://doi. org/10.3233/jpd-150664 
146. Yeh Y-C, Liu C-L, Peng L-N, Lin M-H, Chen L-K (2013) Potential benefits of reducing medication-related anticholinergic burden for demented older adults: a prospective cohort study. Geriatr Gerontol Int 13(3):694-700. https://doi.org/10.1111/ggi. 12000

147. Zia A, Kamaruzzaman S, Myint PK, Tan MP (2016) Anticholinergic burden is associated with recurrent and injurious falls in older individuals. Maturitas 84:32-37. https://doi.org/10. 1016/j.maturitas.2015.10.009

148. Ziad A, Olekhnovitch R, Ruiz F, Berr C, Begaud B, Goldberg M, Zins M, Mura T (2018) Anticholinergic drug use and cognitive performances in middle age: findings from the CONSTANCES cohort. J Neurol Neurosurg Psychiatry 89(10):1107-1115. https:// doi.org/10.1136/jnnp-2018-318190

149. Zimmerman KM, Salow M, Skarf LM, Kostas T, Paquin A, Simone MJ, Rudolph J (2014) Increasing anticholinergic burden and delirium in palliative care inpatients. Palliat Med 28(4):335341. https://doi.org/10.1177/0269216314522105
150. Koo TK, Li MY (2016) A Guideline of selecting and reporting intraclass correlation coefficients for reliability research. J Chiropr Med 15(2):155-163. https://doi.org/10.1016/j.jcm.2016.02.012

151. Lertxundi U, Domingo-Echaburu S, Hernandez R, Peral J, Medrano J (2013) Expert-based drug lists to measure anticholinergic burden: similar names, different results. Psychogeriatrics 13(1):17-24. https://doi.org/10.1111/j.1479-8301.2012.00418.x

152. Ruxton K, Woodman RJ, Mangoni AA (2015) Drugs with anticholinergic effects and cognitive impairment, falls and all-cause mortality in older adults: A systematic review and meta-analysis. Br J Clin Pharmacol 80(2):209-220. https://doi.org/10.1111/bcp. 12617

153. Siering U, Eikermann M, Hausner E, Hoffmann-Esser W, Neugebauer EA (2013) Appraisal tools for clinical practice guidelines: a systematic review. PLoS One 8(12):e82915. https://doi. org/10.1371/journal.pone.0082915

Publisher's note Springer Nature remains neutral with regard to jurisdictional claims in published maps and institutional affiliations. 